\title{
p53, p21, and cyclin d1 protein expression patterns in patients with breast cancer
}

\author{
Marwa Mohammed Ali Jassim¹ ${ }^{1}$, Khetam Habeeb Rasool2(i) and Majid Mohammed Mahmood² (i) \\ 1. Department of Basic Science, College of Dentistry, Al-Muthanna University, Al-Muthanna, Iraq; 2. Department of \\ Biology, College of Science, Mustansiriyah University, Baghdad, Iraq. \\ Corresponding author: Majid Mohammed Mahmood, e-mail: majidmahmood93@yahoo.com \\ Co-authors: MMAJ: marwa.mohammed@mu.edu.iq, KHR: dr.khr@uomustansiriyah.edu.iq \\ Received: 18-07-2021, Accepted: 20-09-2021, Published online: 31-10-2021
}

doi: www.doi.org/10.14202/vetworld.2021.2833-2838 How to cite this article: Jassim MMA, Rasool KH, Mahmood MM (2021) p53, p21, and cyclin d1 protein expression patterns in patients with breast cancer, Veterinary World, 14(10): 2833-2838.

\begin{abstract}
Background and Aim: The mutation in the wild-type tumor suppressor gene p53 is the most common genetic change in human tumors. In addition, the normal function of p21, which is both antiproliferative and an inhibitor of the cell cycle, is disrupted in some types of cancer. Meanwhile, cyclin D1 is a member of the cyclin protein family that is involved in regulating cell cycle progression. This study aimed to assess the expressions of the cell cycle inhibitory proteins p21, cyclin D1, and tumor suppressor gene p53, as well as their influence on the expressed histopathological changes in breast cancer tissues.

Materials and Methods: Overall, 40 breast tissue specimens were investigated in this study, 30 of which were cancerous, while 10 were healthy tissues. p53, p21, and cyclin D1 expression patterns were detected using an immunohistochemistry (IHC) system.

Results: The IHC reactions for p53 were positively observed in 27/30 (90\%) cancerous tissues, compared with $2 / 10(20 \%)$ normal breast tissues. For p21, reactions were observed in 28/30 (93.33\%) cancerous tissues and 3/10 (30\%) control tissues. For cyclin D1, reactions were observed in 25/30 (83.33\%) cancerous tissues and 1/10 (10\%) control tissues. The differences between the breast cancer tissues and the control tissues were statistically highly significant $(\mathrm{p}<0.01)$.

Conclusion: The high expression rates of p21, cyclin D1, and p53 in malignant breast cancer cells with little or no regulatory role might imply mutational events in these proteins operating in concert with a variety of other genetic mutations in these tissues, which may play a molecular role in the development and/or progression of breast carcinogenesis.
\end{abstract}

Keywords: breast cancer, D1 protein, Iraq, P21, P53.

\section{Introduction}

Breast carcinogenesis is a multistage transformation emerging from a combination of hereditary and environmental factors that lead to the advanced accumulation of epigenetic and genetic alterations in the cells of breast tissue [1,2]. The annual incidence rate of breast cancer ranges from $1 \%$ to $2 \%$ in developed countries; in less developed countries, the increase in the incidence can be up to 5\% from that of developed countries. Worldwide, it was expected that the number of new cases would increase from 10 to 15 million in 2020 [3]. The primary cancer suppressor gene is p53, which functions as a proliferation inhibitor and eliminator of anomalous cells, ultimately preventing tumor growth. Cellular stress is the main activator of p53, depending on the upstream regulatory kinase [4]. The mutation in the p53 gene remains the most common genetic change identified in human neoplasia.

Copyright: Jassim, et al. Open Access. This article is distributed under the terms of the Creative Commons Attribution 4.0 International License (http://creativecommons.org/licenses/by/4.0/), which permits unrestricted use, distribution, and reproduction in any medium, provided you give appropriate credit to the original author(s) and the source, provide a link to the Creative Commons license, and indicate if changes were made. The Creative Commons Public Domain Dedication waiver (http://creativecommons.org/ publicdomain/zero/1.0/) applies to the data made available in this article, unless otherwise stated.
The functions of the gene can be lost, and cells in the G1/S phase will not arrest, resulting in the continuous replication of cells, which may result in the instability of genomes and the accumulation of deoxyribonucleic acid (DNA) mutations. Such events are associated with aggressive diseases and worse overall survival [5].

The cyclin-dependent kinase (CDK) inhibitor (p21) is the most important negative regulator of the cell cycle. In response to DNA damage, it is stimulated by p53 and arrests the cell cycle at the G1 phase to allow for DNA repair [6]. Furthermore, p21 can interact with several transcription factors, such as the inhibition of E2F protein complements and effects on cyclin/CDK complexes, to enhance the suppression of E2F genes and induce cell cycle arrest. Considered as a tumor suppressor, dysregulation of the p21 gene has been documented in various human tumors, including breast cancer [7]. The cell cycle is controlled by a family of cyclins and CDK through phosphorylation and dephosphorylation events. Cyclin D1 is produced during the G1 phase just before the checkpoint and plays the main role in the restriction (R) point regulation [8]. Elevated levels of G1 cyclins (D1, E), which are observed in some types of tumors, can result in uncontrolled cell proliferation. During the shift from G1 to S phase, cyclin D1 reaches the maximum level of expression 
and forms an active kinase complex with CDK4 or CDK6. The active cyclin/CDK complexes can then be regulated by binding to CDK inhibitors (p16 and $\mathrm{p} 21$ ), resulting in the inhibition of cell cycle progression from $\mathrm{G} 1$ to $\mathrm{S}$ phase $[9,10]$.

This study aimed to investigate the expected roles of a number of cell cycle regulators, as well as a group of tumor suppressor genes, in Iraqi patients with breast carcinomas and compare their results to a healthy control group using modern molecular techniques. In addition, this study will evaluate the expression of these genes and their impact on the expressed histopathological alterations.

\section{Materials and Methods}

\section{Ethical approval}

The study was approved by Mustansiriyah University, College of Science, Department of Biology (Approval no.257).

\section{Study period and location}

The study was conducted in March to August 2020. The block samples were collected from patients admitted to the surgical wards and from those who were subjected to biopsies and archived at the histopathological laboratories of the Medical City, Baghdad, Iraq, while the tests were conducted in the laboratories of the Medical College, University of Baghdad, Baghdad.

\section{Experimental design}

Tissue processing and slide preparation

A total of 40 paraffin-embedded breast tissue blocks were investigated in this study, 30 of which belonged to females with breast cancer, while 10 belonged to females with normal breasts. The age of the women ranged between 40 and 60 years. Paraffinembedded tissue samples from malignant and control tissues were subjected to serial sectioning at $4 \mu \mathrm{m}$ thickness using a manual microtome with a specific microtome blade for each tissue block. One serial section was taken and mounted on an ordinary glass slide to confirm histopathological examination using hematoxylin and eosin staining, whereas other tissue sections mounted on positively charged slides were used for the following purposes.

The expressions of $\mathrm{p} 53$, cyclin $\mathrm{D} 1$, and $\mathrm{p} 21$ genes in the study groups were assessed using specific immunohistochemistry (IHC) using monoclonal rabbit anti-P53, anti-P21, and anti-cyclin D1 antibodies (cat. nos.: ab131442, ab109520, and ab16663), respectively, and targeting of nuclear specific proteins was performed following the IHC detection kit manufacturer's instructions (Abcam, UK). The scoring and intensity of the signals were assessed using light microscopy $(100 \times)$, according to the methods of Papamitsou et al. [11]. The primary concentrated antibodies were diluted to optimal concentration using phosphate-buffered saline (PBS, pH: 3.5); p21, cyclin D1, and $\mathrm{p} 53$ were diluted to 1:50.

\section{Chromogen/substrate mixture}

3,3'-Diaminobenzidine (DAB) chromogen (Abcam) $(30 \mathrm{~L})$ was added to DAB substrate $(1.5 \mathrm{~mL})$ and thoroughly mixed.

\section{Preparation of slides}

1. Each paraffin-embedded tissue block was sectioned to a thickness of $4 \mu \mathrm{m}$ and mounted on charged slides

2. The sections were deparaffinized overnight in an oven at $60^{\circ} \mathrm{C}$

3. The sections were rehydrated by serially dipping the slides in xylene $(100 \%)$ twice for $15 \mathrm{~min}$, ethanol $(100 \%)$ twice for $5 \mathrm{~min}$, ethanol (95\%) once for $5 \mathrm{~min}$, ethanol (70\%) once for $5 \mathrm{~min}$, ethanol (50\%) once for $5 \mathrm{~min}$, and PBS once for $5 \mathrm{~min}$

4. The slides were allowed to dry at room temperature $\left(25^{\circ} \mathrm{C}\right)$ for $5 \mathrm{~min}$

5. In a dropwise manner, $0.3 \% \mathrm{H}_{2} \mathrm{O}_{2}$ was added to cover the sections, which were incubated for 15 min before being rinsed twice in PBS buffer

6. The slides were immersed in a jar containing the epitope retrieval solution (sodium citrate buffer, $\mathrm{pH}$ 6), which was put in a water bath at $95^{\circ} \mathrm{C}$ for 20-25 min

7. The slides were washed twice with gentle agitation in PBS, and tissue paper was used to wipe the surrounding area of the sections

8. After blocking the slides with protein block, they were incubated at $25^{\circ} \mathrm{C}$ for $1 \mathrm{~h}$

9. The slides were washed once in PBS

10. Each slide was treated with $30-50 \mu$ L of the diluted primary antibody and incubated as directed by the manufacturer

11. The slides were washed thrice in PBS

12. Complement was applied, and the slides were incubated at $25^{\circ} \mathrm{C}$ for $20 \mathrm{~min}$

13. The slides were washed twice in PBS

14. HRP conjugate was added to the slides, which were incubated at $25^{\circ} \mathrm{C}$ for $40 \mathrm{~min}$

15. The slides were rinsed 4 times in PBS

16. The slides were incubated for $10 \mathrm{~min}$ at $25^{\circ} \mathrm{C}$ with a combination of $\mathrm{DAB}$ chromogen and $\mathrm{DAB}$ substrate

17. The slides were rinsed 4 times with PBS

18. Counterstaining was applied to the tissue for 3-5 min before being rinsed for 2 min under running tap water

19. The slides were dehydrated and cleared by serial dipping in ethanol $(50 \%)$ once for $5 \mathrm{~min}$, ethanol $(70 \%)$ once for $2 \mathrm{~min}$, ethanol $(95 \%)$ once for $2 \mathrm{~min}$, ethanol $(100 \%)$ twice for $2 \mathrm{~min}$, ethanol $(100 \%)$ twice for $2 \mathrm{~min}$, ethanol (100\%) twice for $2 \mathrm{~min}$, and xylene (100\%) twice for $2 \mathrm{~min}$

20. A mounting solution was used to mount the slides.

\section{Statistical analysis}

The statistical analysis was performed using SPSS program version 21.0 (IBM, NY, USA). 
Chi-square test and odds ratios were used to evaluate the significant differences between the study groups. The differences among the studied groups were considered statistically significant at $\mathrm{p}<0.05$.

\section{Results}

\section{p53 expression}

Figure-1 displays a micrograph of p53 IHCpositive signals in the breast carcinoma tissues, which were observed as a brownish discoloration with nuclear and cytoplasmic localization under highpower field analysis.

The results of the p53 IHC signal intensity and its scoring distribution in the breast tissues are shown in Table-1. Reactions with low (1+), moderate (2+), and high $(3+)$ signal scores of $\mathrm{p} 53 \mathrm{IHC}$ reactions were expressed in 5 (16.67\%), 9 (30\%), and 13 (43.33\%) samples, respectively, while no signal was expressed in $3(10 \%)$ samples.

In comparison, strong p53 IHC reactions were not observed in healthy tissues, with low $(1+)$ and moderate (2+) signals collectively occurring in $20 \%$ of the samples, while no signal was observed in the rest $(80 \%)$. The results of the odds ratio showed that the breast cancer samples had the highest value (3.271). Overall, there were significant variations $(p<0.01)$ between the examined groups.

\section{p21 expression}

The results of the signal scoring and strength of p21 expression in the breast cancer tissues are shown in Table-2 (for cancerous ones) as well as control tissues. In the breast cancer group, high $(3+)$, low $(1+)$,
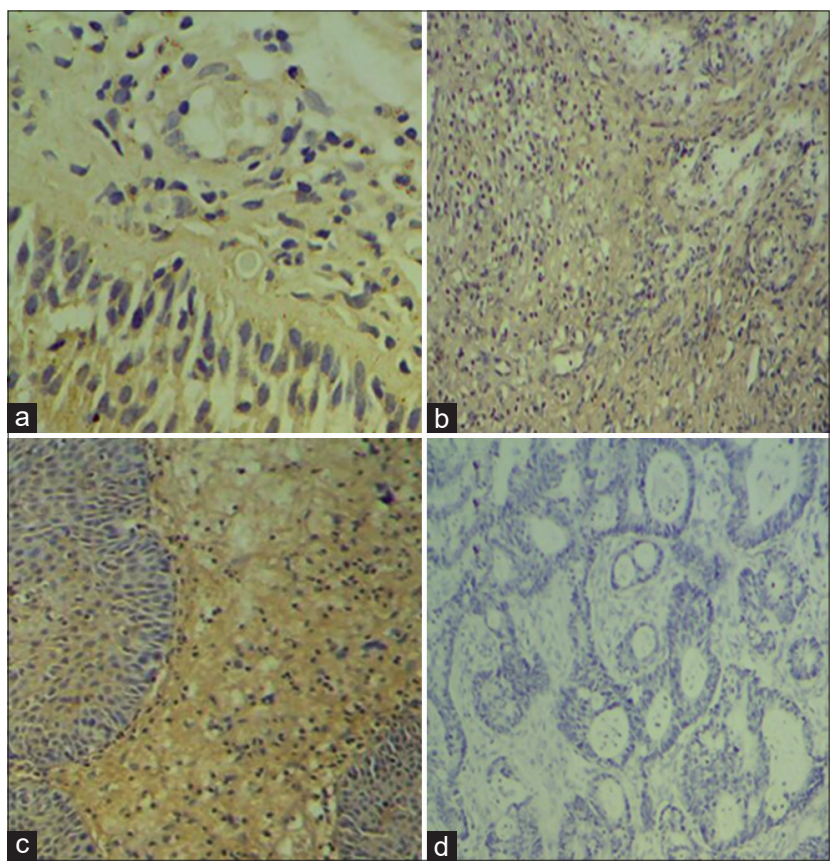

Figure-1: Representative images of breast carcinomas tissues staining for p53 (a), p21 (b), and cyclin D1 (c) expression patterns. These panels represent positive cases for each protein expression pattern that appeared as a brown discoloration at the nuclear and cytoplasmic locations, whereas panel (d) portrays a tumor in which the corresponding protein is not expressed. and moderate $(2+)$ signals for $\mathrm{p} 21 \mathrm{IHC}$ reactions were expressed in $56.67 \%, 23.33 \%$, and $13.33 \%$ of the samples, respectively, while there was no signal in $6.67 \%$ of the samples. The results of the odds ratio were revealed to be 1.604. In healthy tissues, low $(1+)$ and moderate $(2+)$ signals for $\mathrm{p} 21 \mathrm{IHC}$ reactions were observed in $20 \%$ and $10 \%$ of the samples, respectively, while no sample expressed a strong (3+) signal score. In addition, no signal was observed in the rest of the samples $(70 \%)$.

\section{Cyclin D1 expression}

The results of IHC staining of cyclin D1 are shown in Table-3. Moderate (2+), low (1+), and high signals for cyclin D1 IHC reactions were found in $33.33 \%, 13.33 \%$, and $36.67 \%$ of the samples, respectively, while no signal was found in the rest of the samples $(16.67 \%)$. In healthy tissues, a moderate $(2+)$ signal was expressed in one sample $(10 \%)$, while low $(1+)$ and high $(3+)$ signals for cyclin D1 reactions were not detected in any sample. In addition, $90 \%$ of these samples did not have any signal. The differences among the studied groups were statistically significant $(p<0.05)$. The results of the odds ratio reached 2.351. Protein expression patterns are of particular importance in the development of breast cancer, and IHC has provided tremendous benefits in assessing the predictive and developmental markers in cancer.

\section{Discussion}

The present study investigated the abnormal p53, p21, and cyclin D1 protein expression patterns in carcinomatous breasts. The findings showed that p53 is upregulated and has different scores in breast cancer tissues compared with the normal breast tissues. Archer et al. [12] studied the expression of p53 in advanced breast cancers and discovered that, out of 92 patients, $53(57.6 \%)$ had positive outcomes. Similarly, reports by the previous studies have suggested that p53 overexpression is linked to high grades of breast cancer [13-16]. Increased expression of p53, according to Jin et al. [17], reflects the accumulation of wild-type p53 as a compensatory mechanism of the cell's DNA damage and repair system; however, since mutated p53 protein is not digested as easily as wildtype protein inside tumor cells, it accumulates instead. As a result, high p53 expression can be used as a surrogate marker for $\mathrm{p} 53$ mutation.

Regarding p21, the majority of cases (28/30, 93.33\%) showed positive immunostaining when compared with normal breast tissues $(3 / 10,30 \%)$, which is consistent with previous research $[18,19]$. The exact mechanisms of p21's effect on oncogenesis and development remain unclear, and research on breast cancer has shown contradictory findings. In comparison to non-cancerous tissues, CDKN1A/p21 protein levels were found to be significantly higher in breast cancer tissues. There is mounting evidence that the role of p21 is linked to its cellular localization. 
Table-1: Distribution of P53-IHC signal scoring and intensity in healthy and cancerous breast tissues.

\begin{tabular}{|c|c|c|c|c|c|c|c|}
\hline \multirow{2}{*}{$\begin{array}{l}\text { P53-IHC } \\
\text { signal }\end{array}$} & \multicolumn{3}{|c|}{ Scoring } & \multirow[t]{2}{*}{ Stain } & \multicolumn{3}{|c|}{ Intensity } \\
\hline & $\begin{array}{l}\text { Healthy } \\
\text { control }\end{array}$ & $\begin{array}{c}\text { Breast } \\
\text { carcinoma }\end{array}$ & $\begin{array}{c}\text { Pearson's } \\
\text { Chi-square ( } p \text {-value) }\end{array}$ & & $\begin{array}{l}\text { Healthy } \\
\text { control }\end{array}$ & $\begin{array}{c}\text { Breast } \\
\text { carcinoma }\end{array}$ & $\begin{array}{c}\text { Pearson's } \\
\text { Chi-square ( } p \text {-value) }\end{array}$ \\
\hline $\begin{array}{l}\text { Negative } \\
\mathrm{n} \\
\%\end{array}$ & $\begin{array}{c}8 \\
80.0\end{array}$ & $\begin{array}{c}3 \\
10.0\end{array}$ & $\begin{array}{c}p=0.00 \text { highly sign. } \\
(p<0.01)\end{array}$ & $\begin{array}{l}\text { No stain } \\
\mathrm{n} \\
\%\end{array}$ & $\begin{array}{c}8 \\
80.0\end{array}$ & $\begin{array}{c}3 \\
10.0\end{array}$ & $\begin{array}{c}\mathrm{p}=0.027 \text { sign. } \\
(\mathrm{p}<0.05)\end{array}$ \\
\hline+ & & & & Weak & & & \\
\hline $\mathrm{n}$ & 1 & 5 & & $\mathrm{n}$ & 2 & 4 & \\
\hline$\%$ & 10.0 & 16.67 & & & 20.0 & 13.33 & \\
\hline++ & & & & Moderate & & & \\
\hline $\mathrm{n}$ & 1 & 9 & & $\mathrm{n}$ & 0 & 6 & \\
\hline$\%$ & 10.0 & 30.0 & & $\%$ & 0.0 & 20.0 & \\
\hline+++ & & & & Strong & & & \\
\hline $\mathrm{n}$ & 0 & 13 & & $\mathrm{n}$ & 0 & 17 & \\
\hline$\%$ & 0.0 & 43.33 & & $\%$ & 0.0 & 56.67 & \\
\hline Total & & & & Total & & & \\
\hline $\mathrm{n}$ & 10 & 30 & & $\mathrm{n}$ & 10 & 30 & \\
\hline$\%$ & 100.0 & 100.0 & & $\%$ & 100.0 & 100.0 & \\
\hline Odds ratio & & .271 & & Odds ratio & & 271 & \\
\hline
\end{tabular}

$-=$ Highly significant difference at $p<0.01$ and significant at $p<0.05$ using Pearson's Chi-square test. $+=$ Referred to low p53 signal score, $++=$ Moderate signal score, $+++=$ Strong signal score

Table-2: The P21-IHC distribution of signal scoring and intensity in healthy and cancerous breast tissues.

\begin{tabular}{|c|c|c|c|c|c|c|c|}
\hline \multirow{2}{*}{$\begin{array}{l}\text { P21-IHC } \\
\text { signal }\end{array}$} & \multicolumn{3}{|c|}{ Scoring } & \multirow[t]{2}{*}{ Stain } & \multicolumn{3}{|c|}{ Intensity } \\
\hline & $\begin{array}{l}\text { Healthy } \\
\text { control }\end{array}$ & $\begin{array}{c}\text { Breast } \\
\text { carcinoma }\end{array}$ & $\begin{array}{c}\text { Pearson's Chi-square } \\
\text { (p-value) }\end{array}$ & & $\begin{array}{l}\text { Healthy } \\
\text { control }\end{array}$ & $\begin{array}{c}\text { Breast } \\
\text { carcinoma }\end{array}$ & $\begin{array}{c}\text { Pearson's Chi-square } \\
\text { (p-value) }\end{array}$ \\
\hline Negative & & & $\mathrm{p}=0.007$ highly sign. & No stain & & & $p=0.041$ sign. $(p<0.05)$ \\
\hline n & 7 & 2 & $(p<0.01)$ & $\mathrm{n}$ & 7 & 2 & \\
\hline$\%$ & 70.0 & 6.67 & & $\%$ & 70.0 & 6.67 & \\
\hline+ & & & & Weak & & & \\
\hline $\mathrm{n}$ & 2 & 7 & & $n$ & 3 & 6 & \\
\hline$\%$ & 20.0 & 23.33 & & $\%$ & 30.0 & 20.0 & \\
\hline++ & & & & Moderate & & & \\
\hline $\mathrm{n}$ & 1 & 4 & & $\mathrm{n}$ & 0 & 10 & \\
\hline$\%$ & 10.0 & 13.33 & & $\%$ & 0.0 & 33.33 & \\
\hline+++ & & & & Strong & & & \\
\hline $\mathrm{n}$ & 0 & 17 & & $\mathrm{n}$ & 0 & 12 & \\
\hline$\%$ & 0.0 & 56.67 & & $\%$ & 0.0 & 40.0 & \\
\hline Total & & & & Total & & & \\
\hline $\mathrm{n}$ & 10 & 30 & & $\mathrm{n}$ & 10 & 30 & \\
\hline$\%$ & 100.0 & 100.0 & & $\%$ & 100.0 & 100.0 & \\
\hline Odds ratio & & .604 & & Odds ratio & & .604 & \\
\hline
\end{tabular}

$-=$ Highly significant difference at $p<0.01$ and significant at $p<0.05$ using Pearson Chi-square test. $+=$ Referred to low p21 signal score, $++=$ Moderate signal score, $+++=$ Strong signal score

When $\mathrm{p} 21$ is found in the cytoplasm, it acts as an oncogene, encouraging cell proliferation and progression through the cell cycle, whereas nuclear p21 has been implicated in pro-differentiating and senescence-inducing effects [20]. Furthermore, it has been documented that cells in breast and ovarian cancers often coexpress p21 and cyclin D1 genes, resulting in growth arrest [21]. As a result, the coexpression of cell cycle inducers and inhibitors may suggest that these tumors retain key aspects of canonical cell cycle regulation.

Cyclin D1 positivity was also detected in the majority $(25 / 30,83.33 \%)$ of breast cancer sections compared with normal breast sections $(1 / 10,10 \%)$. It is an important regulator of the cell cycle that performs a central role in the pathogenesis of cancer and determines uncontrolled cellular proliferation; the cyclin
D1 gene (CCND1) is amplified in approximately $20 \%$ of mammary carcinomas. Recently, in vitro and in vivo studies have established cyclin D1 as a controller of cellular invasiveness and aggressiveness. Cyclin D1 overexpression is a key determinant of the reciprocal interaction between cancer cells and the stroma, resulting in a "tumor-promoting" effect [22]. Assessing the role of each feature of cyclin D1 in cancer progression could aid in the development of therapies that are more precisely targeted and customized.

Breast carcinogenesis is considered to be accelerated by aberrant cyclin D1 overexpression, which is mediated by the cell cycle. It has been shown that inducing cyclin D1 is necessary to complete the cell cycle in cells arrested in the early G1 process by binding to a CDK4/CDK6 and inactivating the retinoblastoma protein in the cell cycle $[21,22]$. 
Table-3: The immunohistochemical results of cyclin D1 signal scoring and intensity in healthy and cancerous breast tissues.

\begin{tabular}{|c|c|c|c|c|c|c|c|}
\hline \multirow{2}{*}{$\begin{array}{l}\text { Cyclin D1- } \\
\text { IHC signal }\end{array}$} & \multicolumn{3}{|c|}{ Scoring } & \multirow[t]{2}{*}{ Stain } & \multicolumn{3}{|c|}{ Intensity } \\
\hline & $\begin{array}{l}\text { Healthy } \\
\text { control }\end{array}$ & $\begin{array}{c}\text { Breast } \\
\text { carcinoma }\end{array}$ & $\begin{array}{c}\text { Pearson's } \\
\text { Chi-square (P-value) }\end{array}$ & & $\begin{array}{l}\text { Healthy } \\
\text { control }\end{array}$ & $\begin{array}{l}\text { Breast } \\
\text { carcinoma }\end{array}$ & $\begin{array}{c}\text { Pearson's } \\
\text { Chi-square ( } p \text {-value) }\end{array}$ \\
\hline $\begin{array}{l}\text { Negative } \\
\text { n } \\
\%\end{array}$ & $\begin{array}{c}9 \\
90.0\end{array}$ & $\begin{array}{c}5 \\
16.67\end{array}$ & $\begin{array}{c}p=0.047 \text { sign. } \\
(p<0.05)\end{array}$ & $\begin{array}{l}\text { No stain } \\
\mathrm{n} \\
\%\end{array}$ & $\begin{array}{c}9 \\
90.0\end{array}$ & $\begin{array}{c}5 \\
16.67\end{array}$ & $\begin{array}{c}p=0.039 \text { sign. } \\
(p<0.05)\end{array}$ \\
\hline+ & & & & Weak & & & \\
\hline $\mathrm{n}$ & 0 & 4 & & $\mathrm{n}$ & 1 & 6 & \\
\hline$\%$ & 0.0 & 13.33 & & $\%$ & 10.0 & 20.0 & \\
\hline++ & & & & Moderate & & & \\
\hline $\mathrm{n}$ & 1 & 10 & & $\mathrm{n}$ & 0 & 9 & \\
\hline$\%$ & 10.0 & 33.33 & & $\%$ & 0.0 & 30.0 & \\
\hline+++ & & & & Strong & & & \\
\hline $\mathrm{n}$ & 0 & 11 & & $\mathrm{n}$ & 0 & 10 & \\
\hline$\%$ & 0.0 & 36.67 & & $\%$ & 0.0 & 33.33 & \\
\hline Total & & & & Total & & & \\
\hline $\mathrm{n}$ & 10 & 30 & & $\mathrm{n}$ & 10 & 30 & \\
\hline$\%$ & 100.0 & 100.0 & & $\%$ & 100.0 & 100.0 & \\
\hline Odds ratio & & .351 & & Odds ratio & & 351 & \\
\hline
\end{tabular}

$-=$ Highly significant difference at $p<0.01$ and significant at $p<0.05$ using Pearson's Chi-square test. $+=$ Referred to low cyclin D1 signal score, $++=$ Moderate signal score,$+++=$ Strong signal score

The current study used IHC to examine p53, $\mathrm{p} 21$, and cyclin D1 expressions in breast tissue in an Iraqi population, and the study confirmed their essential roles in the cellular events associated with breast carcinogenesis. However, the sample size should be increased in the future to better understand and validate our results, which is of promising importance in the axes of prediction, diagnosis, treatment, and follow-up of breast cancer.

\section{Conclusion}

The high expression rates of $\mathrm{p} 21$, cyclin D1, and p53 in malignant breast cancer cells with little or no regulatory role might imply mutational events in these proteins operating in concert with a variety of other genetic mutations in these tissues, which may play a molecular role in the development and/or progression of breast carcinogenesis.

\section{Authors' Contributions}

MMAJ and MMM: Planned and conceptualized the study. MMAJ, MMM, and KHR: Carried out the experiments, analyzed the data, performed the laboratory analysis, as well as the curation of the data. MMAJ and MMM: Wrote the draft of the manuscript. KHA: Reviewed and edited the manuscript. All authors read and approved the final manuscript.

\section{Acknowledgments}

The authors are thankful to Mustansiriyah University, College of Medicine; University of Baghdad; and Medical City Hospital, for providing laboratory facilities for the study. The authors did not receive any funds for this study.

\section{Competing Interests}

The authors declare that they have no competing interests.

\section{Publisher's Note}

Veterinary World remains neutral with regard to jurisdictional claims in published institutional affiliation.

\section{References}

1. López-Cortés,A., Cabrera-Andrade,A., Vázquez-Naya, J.M., Pazos, A., Gonzáles-Díaz, H., Paz-Y-Miño, C., Guerrero, S., Pérez-Castillo, Y., Tejera, E. and Munteanu, C.R. (2020) Prediction of breast cancer proteins involved in immunotherapy, metastasis, and RNA-binding using molecular descriptors and artificial neural networks. Sci. Rep., 10(1): 1-13.

2. Al-Abassi,H.M.,Almohaidi,A.M.S. and ALMusawi,A.A.R. (2018) Determination of Integrin 22 (ITGA2), Progesterone, prolactin, estradiol, zinc and Vitamin $\mathrm{C}$ in serum of female Iraqi patients with breast cancer. Ibn AL-Haitham J. Pure Appl. Sci., 73-86.

3. Momenimovahed, Z. and Salehiniya, H. (2019) Epidemiological characteristics of and risk factors for breast cancer in the world. Breast Cancer, 11: 151-164.

4. Santoro, A., Vlachou, T., Luzi, L., Melloni, G., Mazzarella, L., D’Elia, E., Aobuli, X., Pasi, C.E., Reavie, L., Bonetti, P., Punzi, S., Casoli, L., Sabò, A., Moroni, M.C., Dellino, G.I., Amati, B., Nicassio, F., Lanfrancone, L. and Pelicci, P.G. (2019) p53 loss in breast cancer leads to Myc activation, increased cell plasticity, and expression of a mitotic signature with prognostic value. Cell Rep., 26(3): 624-638.

5. Shahbandi, A., Nguyen, H.D. and Jackson, J.G. (2020) TP53 mutations and outcomes in breast cancer: Reading beyond the Headlines. Trends Cancer, 6(2): 98-110.

6. Zohny, S.F., Al-Malki, A.L., Zamzami, M.A. and Choudhry, H. (2019) p21 Waf1/Cip1: Its paradoxical effect in the regulation of breast cancer. Breast Cancer, 26(2): 131-137.

7. Li, Y., Huang, J., Yang, D., Xiang, S., Sun, J., Li, H. and Ren, G. (2018) Expression patterns of E2F transcription factors and their potential prognostic roles in breast cancer. Oncol. Lett., 15(6): 9216-9230.

8. Niu, Y., Xu, J. and Sun, T. (2019) Cyclin-dependent kinases 4/6 inhibitors in breast cancer: Current status, resistance, and combination strategies. J. Cancer, 10(22): 5504.

9. Spring, L.M., Wander, S.A., Andre, F., Moy, B., Turner, N.C. and Bardia, A. (2020) Cyclin-dependent kinase 4 and 6 inhibitors for hormone receptor-positive breast cancer: Past, 
present, and future. Lancet, 395(10226): 817-827.

10. Ding, L., Cao, J., Lin, W., Chen, H., Xiong, X., Ao, H., Yu, M., Lin, J. and Cui, Q. (2020) The roles of cyclin-dependent kinases in cell-cycle progression and therapeutic strategies in human breast cancer. Int. J. Mol. Sci., 21(6): 1960.

11. Papamitsou, T., Toskas, A., Papadopoulou, K., Sioga, A., Lakis, S., Chatzistamatiou, M., Economou, Z. and Adriopoulou, L. (2014) Immunohistochemical study of immunological markers: HLAG, CD16, CD25, CD56, and CD68 in placenta tissues in recurrent pregnancy loss. Histol. Histopathol., 29(8): 1047-1055.

12. Archer, S.G., Eliopoulos, A., Spandidos, D., Barnes, D., Ellis, I.O., Blamey, R.W., Nicholson, R.I. and Robertson, J.F.R. (1995) Expression of ras p21, p53, and c-erb B-2 in advanced breast cancer and response to first line hormonal therapy. Br. J. Cancer, 72(5): 1259-1266.

13. Sekar, P., Bharti, J.N., Nigam, J.S., Sharma, A. and Soni, P.B. (2014) Evaluation of p53, HoxD10, and E-cadherin status in breast cancer and correlation with histological grade and other prognostic factors. J. Oncol., 2014: 702527.

14. Sadia, H., Bhinder, M.A., Irshad, A., Zahid, B., Ahmed, R., Ashiq, S., Malik, K., Riaz, M., Nadeem, T., Ashiq, K. and Akbar, A. (2020) Determination of expression profile of p53 gene in different grades of breast cancer tissues by realtime PCR. Afr. Health Sci., 20(3): 1273-1282.

15. Li, J.P., Zhang, X.M., Zhang, Z., Zheng, L.H., Jindal, S. and Liu, Y.J. (2019) Association of p53 expression with poor prognosis in patients with triple-negative breast invasive ductal carcinoma. Medicine, 98(18): e15449.

16. Hashmi, A.A., Naz, S., Hashmi, S. K., Hussain, Z.F., Irfan, M., Khan, E.Y., Faridi, N., Khan, A. and Edhi, M.M. (2018) Prognostic significance of p16 \& p53 immunohistochemical expression in triple-negative breast cancer. BMC Clin. Pathol., 18(1): 9.

17. Jin, M.S., Park, I.A., Kim, J.Y., Chung, Y.R., Im, S.A., Lee, K.H. and Ryu, H.S. (2016) New insight on the biological role of $\mathrm{p} 53$ protein as a tumor suppressor: Re-evaluation of its clinical significance in triple-negative breast cancer. Tumour Biol., 37(8): 11017-11024.

18. Thor, A.D., Liu, S., Moore Ii, D.H., Shi, Q. and Edgerton, S.M. (2000) p21 WAF1/CIP1 expression in breast cancers: Associations with p53 and outcome. Breast Cancer Res. Treat., 61(1): 33-43.

19. Wei, C.Y., Tan, Q.X., Zhu, X., Qin, Q.H., Zhu, F.B., Mo, Q.G. and Yang, W.P. (2015) Expression of CDKN1A/p21 and TGFBR2 in breast cancer and their prognostic significance. Int. J. Clin. Exp. Pathol., 8(11): 14619-14629.

20. Liu, K.H., Huynh, N., Patel, O., Shulkes, A., Baldwin, G. and He, H. (2013) P21-activated kinase 1 promotes colorectal cancer survival by up-regulation of hypoxia-inducible factor-1 $\alpha$. Cancer Lett., 340(1): 22-29.

21. Zagouri, F., Kotoula, V., Kouvatseas, G., Sotiropoulou, M., Koletsa, T., Gavressea, T., Valavanis, C., Trihia, H., Bobos, M., Lazaridis, G., Koutras, A., Pentheroudakis, G., Skarlos, P., Bafaloukos, D., Arnogiannaki, N., Chrisafi, S., Christodoulou, C., Papakostas, P., Aravantinos, G., Kosmidis, P., Karanikiotis, C., Zografos, G., Papadimitriou, C. and Fountzilas, G. (2017) Protein expression patterns of cell cycle regulators in operable breast cancer. PLoS One, 12(8): e0180489.

22. Montalto, F.I. and DeAmicis, F. (2020) Cyclin D1 in cancer: A molecular connection for cell cycle control, adhesion, and invasion in tumor and stroma. Cells, 9(12): 2648. 